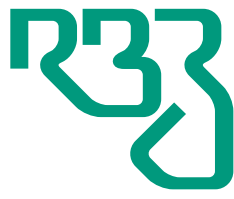

Revista

Brasileira de

Zootecnia

Brazilian Journal of Animal Science

ISSN 1806-9290

www.rbz.org.br

\title{
Alternative methodologies for genotyping polymorphisms in the CAST and CAPN1 genes in beef cattle
}

\author{
Isabella Maiumi Zaidan Blecha ${ }^{1}$ (iD), Isadora Inácio Sousa ${ }^{1}$ (iD), Anna Beatriz \\ Robottom Ferreira $^{2}$ (iD, Gelson Luis Dias Feijó ${ }^{3}$ (iD), Roberto Augusto de \\ Almeida Torres Júnior ${ }^{3}$ iD, Fabiane Siqueira ${ }^{3 *}$ iD \\ ${ }^{1}$ Universidade Federal de Mato Grosso do Sul, Faculdade de Medicina Veterinária e \\ Zootecnia, Programa de Pós-Graduação em Ciência Animal, Campo Grande, MS, Brasil. \\ ${ }^{2}$ Embrapa Agroindústria de Alimentos, Rio de Janeiro, RJ, Brasil. \\ ${ }^{3}$ Embrapa Gado de Corte, Campo Grande, MS, Brasil.
}

\author{
*Corresponding author: \\ fabiane.siqueira@embrapa.br \\ Received: December 13, 2018 \\ Accepted: September 12, 2019 \\ How to cite: Blecha, I. M. Z.; Sousa, I. I.; Ferreira \\ A. B. R.; Feijó, G. L. D.; Torres Júnior, R. A. A. and \\ Siqueira, F. 2019. Alternative methodologies \\ for genotyping polymorphisms in the CAST and \\ CAPN1 genes in beef cattle. Revista Brasileira de \\ Zootecnia 48:e20180218. \\ https://doi.org/10.1590/rbz4820180218 \\ Copyright: This is an open access article \\ distributed under the terms of the \\ Creative Commons Attribution License \\ (http://creativecommons.org/licenses/by/4.0/), \\ which permits unrestricted use, distribution, \\ and reproduction in any medium, provided the \\ original work is properly cited.
}

ABSTRACT - The objectives of this study were to genotype single nucleotide polymorphisms (SNP) AF159246:g.2959A>G (CAST/DdeI) and AF248054.2:g.6545C>T (CAPN4751) in beef cattle by PCR-RFLP (Polymerase Chain Reaction - Restriction Fragment Length Polymorphism), using the restriction enzyme DdeI for both SNP, and describe the use of these genotyping methodologies for the first time. For the SNP located in the CAST gene, new primers were designed, and for the SNP of the CAPN1 gene, the same primers previously described in the literature were used. Bonsmara, Caracu, Senepol, Nelore, and Angus bulls were chosen from among the most used bulls in breeding programs according to their genealogy and the lowest possible degree of parentage between them to ensure an experimental sample representative of the genetic variability in each breed. For the CAST and CAPN1 genes, respectively, the following number of animals were analyzed: Bonsmara ( $n=25 / 22)$, Caracu $(n=25 / 26)$, Senepol $(n=25 / 24)$, Nelore $(n=26 / 26)$, and Angus $(n=25 / 24)$. The accuracy of these methodologies was confirmed by direct sequencing of PCR products generated for the two polymorphisms. The new primers developed for CAST/DdeI SNP detection and the use of $D d e I$ enzyme for CAPN4751 SNP detection were effective in genotyping, since no inconclusive genotypes were observed for these genes. Thus, the genotyping of beef cattle using the PCR-RFLP technique for CAST and CAPN1 genes is robust, relatively inexpensive, and easy to perform in any basic molecular biology laboratory. If the association of these markers with traits of economic interest in beef cattle is confirmed in new studies, these methodologies may contribute to the selection of animals with superior genetics, i.e., with the potential to produce better-quality meat, either by marker-assisted selection or by the inclusion of these polymorphisms in high-density marker panels.

Keywords: animal breeding, marker-assisted selection, PCR-RFLP, SNP, tenderness

\section{Introduction}

In addition to traditional methods of animal genetic improvement, marker-assisted selection promises to help improve traits associated with beef and carcass quality of cattle. Several studies have been performed in beef cattle to evaluate the effect of known polymorphisms, as well as to prospect new markers in candidate genes associated with traits of economic interest. 
It is in this sense that the calpain/calpastatin enzyme complex has been drawing attention to studies of molecular markers that could be used for the genetic improvement of beef cattle. Calpain is endogenous calcium and cysteine-dependent protease involved in the breakdown of skeletal muscle proteins, which is inhibited by the enzyme calpastatin (Koohmaraie, 1996). This enzyme complex is activated after animal slaughter and is directly involved with meat tenderization during the maturation process. In several studies, it was observed that the greater proportion of Zebu blood in the herd, the less tender is the meat, because of post-mortem increase in the activity of calpastatin (Johnson et al., 1990; Sherbeck et al., 1995; Rubensam et al., 1998; Ferguson et al., 2000; Restle et al., 2003).

Calpastatin enzyme is encoded by the CAST gene located on chromosome 7 (Bishop et al., 1993), while calpain is encoded by the CAPN1 gene found on chromosome 29 (Smith et al., 2000). The nucleotide sequences of these genes are deposited in GenBank (http://www.ncbi.nlm.nih.gov/) under accession numbers AF159246 and AF248054, respectively.

Barendse (2002) identified a single nucleotide polymorphism (SNP) characterized by the transition of an adenine to a guanine in the 3'UTR of the CAST gene (AF159246:g.2959A>G). The PCR-RFLP (Polymerase Chain Reaction-Restriction Fragment Length Polymorphism) methodology described by Curi et al. (2008) to genotype this SNP and amplifies a 269 base pair (bp) fragment that, once digested by the restriction enzyme DdeI, yields either one $269 \mathrm{bp}$ fragment in the case of the $\mathrm{G}$ allele or two fragments in the case of the A allele (137 and $132 \mathrm{bp}$ ). However, since only one restriction site for $D d e$ I is found on this fragment, in cases of suboptimal enzyme performance, an undigested $269 \mathrm{bp}$ fragment may be erroneously interpreted as an individual that presents homozygous genotype GG. In light of this, new PCR primers were developed in this work to amplify a larger region of CAST gene (486 bp), which incorporated an additional DdeI restriction site, thus avoiding technical problems.

Several SNP have been identified in the CAPN1 gene, including CAPN316, CAPN530, CAPN4751, CAPN4753, and CAPN5331 (Page et al., 2002, 2004; White et al., 2005; Casas et al., 2005, 2006). According to White et al. (2005), CAPN4751 is a silent mutation in intron 18 (AF248054.2:g.6545C >T) involving the cytosine to thymine base substitution (C/T) and was the first marker in this gene to be significantly associated with meat tenderness in both Bos taurus taurus and Bos taurus indicus. This marker has been genotyped by multiplex MassArray (White et al., 2005), and the amplification refractory mutation system-polymerase chain reaction (ARMS-PCR) was suggested by Rincón and Medrano (2006).

To genotype this polymorphism with the same technique as that applied for the CAST, PCR was carried out using only the pair of "outer" primers described by Rincón and Medrano (2006). Additionally, the PCR product was digested by $D d e$ I restriction endonuclease.

This study aimed to genotype the SNP AF159246:g.2959A $>$ G, located in the CAST gene, and AF248054.2:g.6545C >T, located in the CAPN1 gene, in beef cattle, by PCR-RFLP methodology using the restriction enzyme $D d e I$ and describe for the first time the use of the new primers for the first SNP and the incorporation of the DdeI restriction enzyme for the second SNP.

\section{Material and Methods}

Blood and semen samples were obtained from Bonsmara, Caracu, and Senepol (adapted taurines), Nelore (zebuine), and Angus (non-adapted taurine) bulls. Samples were obtained from insemination centers, beef cattle breed associations, and breeders. Bulls were selected to have the least possible degree of parentage, determined by their genealogy. Relationship and inbreeding coefficients were determined by scripts developed in MATLAB software (Little and Moler, 2002).

Genomic DNA was extracted from leukocytes and semen using an adapted protocol made by Regitano and Coutinho (2001), who used the protocols described by Olerup and Zetterquist (1992) for leukocytes and Zadworny and Kuhnlein (1990) for semen. Genomic DNA was quantified on a NanoDrop (Thermo Scientific) spectrophotometer and integrity was verified by $0.8 \%$ agarose gel electrophoresis. DNA samples were diluted in TE (10 mM Tris $\mathrm{HCl} \mathrm{pH} \mathrm{7.6;} 1 \mathrm{mM}$ EDTA $)$ and stored in $40 \mathrm{ng} / \mu \mathrm{L}$ aliquots. 
A total of 126 bulls were genotyped for the SNP AF159246:g.2959A>G in the CAST gene (CAST/DdeI): Bonsmara $(\mathrm{n}=25)$, Caracu $(\mathrm{n}=25)$, Senepol $(\mathrm{n}=25)$, Angus $(\mathrm{n}=25)$, and Nelore $(\mathrm{n}=26)$. For the SNP AF248054.2:g.6545C $>$ T in the CAPN1 gene (CAPN4751/DdeI) 122 bulls were genotyped: Bonsmara $(\mathrm{n}=22)$, Caracu $(\mathrm{n}=26)$, Senepol $(\mathrm{n}=24)$, Angus $(\mathrm{n}=24)$ and Nelore $(\mathrm{n}=26)$.

The CAST/DdeI polymorphism involved the amplification of a $486 \mathrm{bp}$ fragment in the $3^{\prime}$ UTR using forward 5'TGAATTTGTCTGGTTCACCTGT3' and reverse primer 5'GACAAGGTGCGGAAGTCCTA3', described in this work for the first time, and was followed by DdeI restriction endonuclease (Curi et al., 2008). The DdeI endonuclease recognizes the 5'C'TNAG 3' site restriction (Invitrogen, USA). For CAPN4751/DdeI, a $334 \mathrm{pb}$ fragment was amplified from the pair of "outer" primers used by White et al. (2005), of which were forward 5' CCTGGAGTCCTGCCGCAGCATGGTCAAC 3' and reverse 5'AAGCTGCAGGAGCTGCCCAAAGCCAGGC3', followed by the digestion using the same restriction endonuclease (DdeI).

The amplification reactions were performed in final volume of $25 \mu \mathrm{L}$ containing $40 \mathrm{ng}$ genomic DNA, $1 \mathrm{X}$ PCR buffer, $1.5 \mathrm{mM} \mathrm{MgCl}_{2}, 0.2 \mathrm{mM}$ dNTP, $1 \mathrm{U}$ Taq DNA polymerase, and $0.2 \mu \mathrm{M}$ of each CAST/DdeI primer or $0.16 \mu \mathrm{M}$ of each CAPN4751/DdeI primer. After initial denaturation at $94{ }^{\circ} \mathrm{C}$ for $5 \mathrm{~min}$, amplification was performed in 30 cycles at $94^{\circ} \mathrm{C}$ for $1 \mathrm{~min}, 58^{\circ} \mathrm{C}$ for either $30 \mathrm{~s}$ (CAPN4751/DdeI) or $1 \mathrm{~min}(\mathrm{CAST} / \mathrm{DdeI})$ and $72^{\circ} \mathrm{C}$ for $1 \mathrm{~min}$, followed by a final extension step at $72{ }^{\circ} \mathrm{C}$ for $5 \mathrm{~min}$. Eight microliters of PCR products were separated and observed by electrophoresis in a 1\% agarose gel.

Aliquots of $7 \mu \mathrm{L}$ of the amplification products were digested with Ddel restriction endonuclease in a final volume of $10 \mu \mathrm{L}$ containing $3 \mu \mathrm{L}$ of digestion mix ( $1 \mathrm{U}$ DdeI, $50 \mathrm{mM}$ Tris- $\mathrm{HCl} \mathrm{pH} \mathrm{8.0,100} \mathrm{mM} \mathrm{NaCl}$, $10 \mathrm{mM} \mathrm{MgCl} 2$ ) at $37^{\circ} \mathrm{C}$ for $4 \mathrm{~h}$. DNA fragments were separated by electrophoresis in a $3 \%$ agarose gel stained with SybrGold $(1: 100,000)$ and photographed.

Based on the genotypes identified on agarose gels, Hardy-Weinberg equilibrium was assessed within breeds using Chi-square $\left(\mathrm{X}^{2}\right)$ test, following the current formula:

$$
x^{2}=\sum_{i=1}^{n} \frac{\left(o_{i}-e_{i}\right)^{2}}{e_{i}}
$$

in which $n$ is number of genotypes, $o_{i}$ is the observed frequency of $i, e_{i}$ is the expected frequency of $i$ $\left(\mathrm{p}^{2}+2 \mathrm{pq}+\mathrm{q}^{2}=1\right)$, and $i$ is the genotypes of each loci.

Allelic and genotypic frequencies were compared by breed, in a pairwise way, using a modified Chi-square $\left(\mathrm{X}^{2}\right)$ test, in which $o_{i}$ is the observed frequency for breed " $\mathrm{A}$ " and $e_{i}$ is the observed frequency for breed "B".

The accuracy of genotyping by PCR-RFLP technique for the SNP AF159246:g.2959A>G (CAST) and AF248054.2:g.6545C >T (CAPN1), using DdeI restriction enzyme, was confirmed through the direct sequencing of PCR products of six individuals for each polymorphism.

\section{Results}

The nucleotide sequences of CAST and CAPN1 genes are deposited in GenBank (http://www.ncbi.nlm. nih.gov/) under accession numbers AF159246 and AF248054.2, respectively.

The digestion of CAST gene resulted in four fragments for the A allele (195, 191, 68, and $32 \mathrm{bp})$ and three fragments for the $\mathrm{G}$ allele $(386,68$, and $32 \mathrm{bp})$. Digestion of heterozygous samples resulted in all five fragments from the combination of both alleles (Figure 1). For the CAPN1 gene, digestion resulted in three fragments for the $T$ allele $(159,63$, and $54 \mathrm{bp})$ and three fragments for the $C$ allele $(213,63$, and $54 \mathrm{bp}$ ). Heterozygous samples also yielded all four possible fragments from the combination of both alleles (Figure 2).

Fragments present in all genotypes, such as the 68 and $32 \mathrm{bp}$ fragments for the CAST gene and the 63 and 54 bp fragments for the CAPN1 gene, were considered controls to warrant that endonuclease digestion took place for each sample, thereby guaranteeing accuracy.

R. Bras. Zootec., 48:e20180218, 2019 


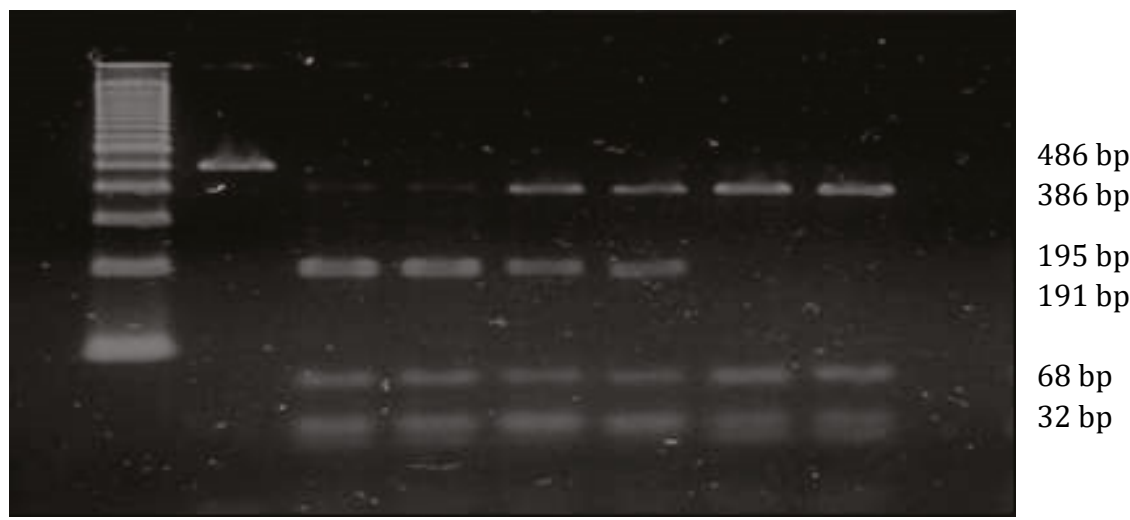

First lane $=$ molecular marker of $100 \mathrm{bp}$; second lane $=486 \mathrm{bp}$ PCR product; third and fourth lanes = homozygote individuals for the allele $\mathrm{A}$ (AA); fourth and fifth lanes = heterozygote individuals (AG); sixth and seventh lanes = homozygote individuals for the allele G (GG); eighth lane $=$ negative control.

Figure 1 - Agarose gel electrophoresis (3\%) of products amplified by PCR and cleaved with restriction endonuclease DdeI for the polymorphism AF159246:g.2959A >G (CAST gene).

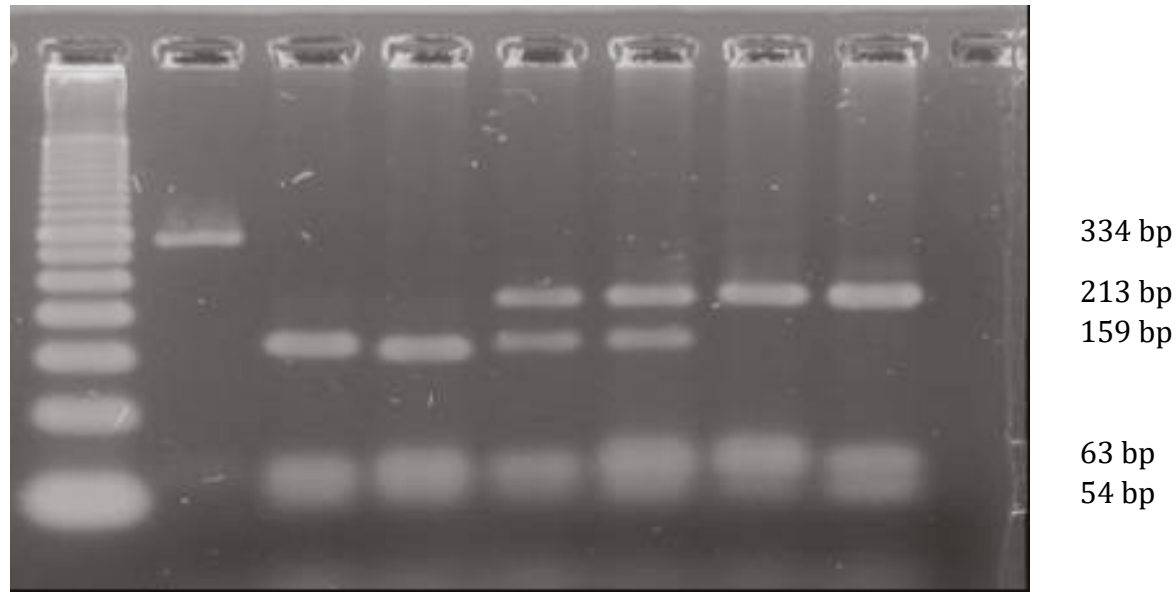

First lane $=$ molecular marker of $50 \mathrm{bp}$; second lane $=334 \mathrm{bp}$ PCR product; third and fourth lanes $=$ homozygote individuals for the allele $\mathrm{T}$ (TT); fourth and fifth lanes = heterozygote individuals (CT); sixth and seventh lanes = homozygote individuals for the allele C (CC); eighth lane $=$ negative control.

Figure 2 - Agarose gel electrophoresis (3\%) of products amplified by PCR and cleaved with restriction endonuclease DdeI for polymorphism AF248054.2:g.6545C>T (CAPN1 gene).

The Bonsmara breed was the only one to present one allelic variant for the AF159246: g.2959A> G (CAST/DdeI) SNP, having only observed individuals with the AA genotype. Allelic frequencies of this polymorphism ranged from $60.0 \%$ (Nelore) to $100.0 \%$ (Bonsmara) for the A allele and $6.0 \%$ (Angus) to $40.0 \%$ (Nelore) for the $\mathrm{G}$ allele (Table 1).

Results of the Chi-square test for the CAST/DdeI polymorphism showed that Angus, Caracu, Nelore, and Senepol breeds are in Hardy-Weinberg equilibrium $(\mathrm{P}>0.05)$, which indicates that the genotypic frequencies remain constant over generations and that the calpastatin gene is not undergoing selective pressures.

However, for the Bonsmara breed, the frequency of heterozygous (AG) and homozygous (GG) animals was less than expected, indicating that the population is not under Hardy-Weinberg equilibrium $(\mathrm{P}<0.05)$. Although the necessary caution was taken in the selection of animals, this may be due to the fact that the animals present a higher degree of relationship than expected, which leads to an overestimation of the sample size. 
Significant differences were observed between genotypic and allelic frequencies between breeds for the CAST/DdeI SNP (Table 1). Two-by-two comparison for genotypic frequency yielded significant differences $(\mathrm{P}<0.05)$ between Bonsmara/Caracu, Bonsmara/Senepol, Bonsmara/Nelore, Caracu/ Angus, Senepol/Angus, and Angus/Nelore but not between Bonsmara/Angus, Caracu/Senepol, Caracu/ Nelore, and Senepol/Nelore (Table 2).

The allelic and genotypic frequencies for the SNP AF248054.2:g.6545C>T (CAPN4751/DdeI) were compared by the Chi-square test and both showed a significant difference $(\mathrm{P}<0.05)$ between breeds (Table 1). The Caracu breed presented the highest frequency (73.1\%) for the $\mathrm{C}$ allele, while the Nelore breed presented the highest frequency (88.5\%) for the $\mathrm{T}$ allele, both compared to the other breeds.

In the two-by-two comparison, for genotypic frequency, the Caracu/Angus, Caracu/Senepol, and Senepol/Angus breeds did not differ significantly between them ( $\mathrm{P}>0.05)$, while the Angus/Nelore, Senepol/Nelore, Caracu/Nelore, Bonsmara/Nelore, Bonsmara/Angus, Bonsmara/Senepol, and Bonsmara/Caracu comparisons yielded significant differences $(\mathrm{P}<0.05)$ for this marker (Table 3 ).

Table 1 - Allelic and genotypic frequencies for the CAPN4751/DdeI and CAST/DdeI polymorphisms for the five bovine breeds

\begin{tabular}{|c|c|c|c|c|c|c|}
\hline Polymorphism & Allele/Genotype & Bonsmara & Caracu & Senepol & Angus & Nelore \\
\hline & $\mathrm{C}$ & 54.55 & 73.08 & 60.42 & 68.75 & 11.54 \\
\hline & $\mathrm{T}$ & 45.45 & 26.92 & 39.58 & 31.25 & 88.46 \\
\hline \multirow[t]{5}{*}{ CAPN4751/DdeI* } & $\mathrm{TT}$ & 4.54 & 7.69 & 16.67 & 8.33 & 76.92 \\
\hline & $\mathrm{CC}$ & 13.64 & 53.85 & 37.50 & 45.84 & 0.00 \\
\hline & CT & 81.82 & 38.46 & 45.83 & 45.83 & 23.08 \\
\hline & A & 100.00 & 68.00 & 76.00 & 94.00 & 60.00 \\
\hline & $\mathrm{G}$ & 0.00 & 32.00 & 24.00 & 6.00 & 40.00 \\
\hline \multirow[t]{3}{*}{ CAST/DdeI* } & AA & 100.00 & 56.00 & 64.00 & 88.00 & 30.77 \\
\hline & GG & 0.00 & 20.00 & 12.00 & 0.00 & 11.54 \\
\hline & $A G$ & 0.00 & 24.00 & 24.00 & 12.00 & 57.69 \\
\hline
\end{tabular}

* Genotypic and allelic frequencies are significantly different among breeds (Chi-square test, $\mathrm{P}<0.01$ ).

Table 2 - Comparison of genotypic (upper diagonal) and allelic (lower diagonal) frequencies for the CAST/DdeI polymorphism by the Chi-square test $\left(\chi^{2}\right)$

\begin{tabular}{|c|c|c|c|c|c|}
\hline & Bonsmara & Caracu & Senepol & Angus & Nelore \\
\hline Bonsmara & & 0.0009 & 0.0041 & 0.2027 & $<0.0001$ \\
\hline Caracu & $<0.0001$ & & 0.3729 & 0.0009 & 0.3786 \\
\hline Senepol & $<0.0001$ & 0.7286 & & 0.0117 & 0.0770 \\
\hline Angus & 0.0786 & 0.0204 & 0.0842 & & 0.0002 \\
\hline Nelore & $<0.0001$ & 0.0503 & 0.0386 & $<0.0001$ & \\
\hline
\end{tabular}

Table 3 - Comparison of genotypic (upper diagonal) and allelic (lower diagonal) frequencies for the CAPN4751/ $D d e$ I polymorphism by the Chi-square test $\left(\chi^{2}\right)$

\begin{tabular}{lccccc}
\hline & Bonsmara & Caracu & Senepol & Angus & Nelore \\
\hline Bonsmara & & 0.0088 & 0.0405 & $<0.0001$ & $<0.0001$ \\
Caracu & 0.0585 & & 0.4223 & 0.8487 & $<0.0001$ \\
Senepol & 0.5692 & 0.1786 & & 0.6483 & $<0.0001$ \\
Angus & $<0.0001$ & 0.6338 & 0.3933 & & $<0.0001$ \\
Nelore & $<0.0001$ & $<0.0001$ & $<0.0001$ & $<0.0001$ & \\
\hline
\end{tabular}




\section{Discussion}

For $C A S T / D d e$ I polymorphism, the Bonsmara breed presented the highest frequency of the A allele (100.0\%), followed by Angus (94.0\%), Senepol (76.0\%), Caracu (68.0\%), and Nelore (60.0\%) (Table 1). This result is consistent with the literature, which has reported Nelore as having the lowest frequency of the A allele, as shown by Curi et al. (2009). Working with 300 animals, the authors found the lower frequencies for Nelore (55.7\%) and Canchim (69.5\%) than for Braunvieh three-cross way (73.3\%), Rubia Galega $\times$ Nelore (82.9\%), Brangus three-cross way (84.2\%), and Angus $\times$ Nelore (89.5\%).

Studying a population of taurine animals, Morris et al. (2006) found frequencies between 84.0 and 99.5\% for the A allele. Casas et al. (2006) also observed a higher frequency of the A allele in taurine animals $(80.0 \%)$ and crossed animals B. taurus taurus $\times$ B. taurus indicus $(83.0 \%)$ than in zebuine animals (72.0\%). According to Rubensam et al. (1998), animals of the $B$. taurus indicus breeds produce less tender meat than animals of the $B$. taurus taurus breeds and their crossings $B$. taurus taurus $\times B$. taurus indicus due to increasing calpastatin enzyme activity when the proportion of zebu blood increase in the animals crossed.

The differences observed between zebuine (Nelore) and taurine (Angus, Bonsmara, and Senepol) breeds are in accordance with literature, suggesting that, as long as association to the traits is confirmed, the CAST/DdeI marker may be used in the selection of animals with better beef quality due to the mediumto-high frequency of the favorable allele in the population.

White et al. (2005) observed an association of the C allele for the CAPN4751 marker with lower values for shear force in pure taurine, taurine crosses, and zebuine $\times$ taurine crosses, which suggest that this allele favors meat tenderness. In the present study, both allelic variants ( $\mathrm{T}$ and $\mathrm{C}$ ) were observed in the five breeds analyzed (Table 1). The $\mathrm{C}$ allele was observed less frequently in Nelore, which was in accordance with the literature that states that zebuine beef presents a higher concentration of calpastatin.

Soria et al. (2010) also observed a lower frequency of the C allele in Brangus and Brahman animals, when compared with Angus breed. The frequency for this allele was 68.0, 55.0, and 5.0\% for Angus, Brangus, and Brahman, respectively, and the authors did not detect the CC genotype in Brahman animals.

White et al. (2005) evaluated genotypic and allelic frequencies of the CAPN4751 marker in three populations. The first population was comprised of B. taurus taurus descendents, the second consisted of $B$. taurus taurus germplasm with influence from B. taurus indicus, and the third was comprised solely by $B$. taurus indicus cattle (pure breed Brahman). The authors observed that the CC genotype was missing in the $B$. taurus indicus population and found that the homozygotes for the $C$ allele presented lower mean shear force than homozygotes for the T allele.

Casas et al. (2006) evaluated the same marker in the same three populations and found significant association for beef tenderness scores in two of the three populations: one comprised of $B$. taurus taurus descendents and the other of $B$. taurus taurus germplasm with influence from $B$. taurus indicus. Authors also showed that bearers of the CC and CT genotypes presented more tender beef $(\mathrm{P}<0.05)$ compared with animals with the TT genotype.

Calpain-calpastatin system studies may help explain differences in bovine beef tenderness, since markers in these genes are highly associated with this trait in both taurine and zebuine breeds, which could help the selection of animals that present superior genetics to produce better-quality meat.

\section{Conclusions}

The PCR-RFLP methodology was successfully used to detect polymorphisms in both CAST and CAPN1 genes using long primers and generating fragments that can be used as quality control for the digestion reaction. These methods are robust, relatively inexpensive, and can be easily carried out in any basic molecular biology laboratory. The results obtained by these methodologies may contribute to the selection of animals with superior genotypes and, thus, for the production of better-quality beef. 


\section{Conflict of Interest}

The authors declare no conflict of interest.

\section{Author Contributions}

Conceptualization: R.A.A. Torres Júnior and F. Siqueira. Formal analysis: I.M.Z. Blecha and F. Siqueira. Funding acquisition: F. Siqueira. Investigation: I.M.Z. Blecha and F. Siqueira. Methodology: I.M.Z. Blecha, I.I. Sousa, A.B.R. Ferreira, G.L.D. Feijó and F. Siqueira. Project administration: F. Siqueira. Resources: R.A.A. Torres Júnior and F. Siqueira. Supervision: F. Siqueira. Writing-original draft: I.M.Z. Blecha and F. Siqueira. Writing-review \& editing: I.M.Z. Blecha, I.I. Sousa, A.B.R. Ferreira and F. Siqueira.

\section{Acknowledgments}

This research was supported by the Empresa Brasileira de Pesquisa Agropecuária (EMBRAPA; project 03.07.05.008.00.00), Fundação de Apoio ao Desenvolvimento do Ensino, Ciência e Tecnologia do Estado de Mato Grosso do Sul (FUNDECT; process 23/200.164/2007), and Coordenação de Aperfeiçoamento de Pessoal de Nível Superior (CAPES).

\section{References}

Barendse, W. J. 2002. DNA markers for meat tenderness. International patent application PCT/AU02/00122. International patent publication WO 02/064820 A1.

Bishop, M. D.; Koohmaraie, M.; Killefer, J. and Kappes, S. 1993. Rapid communication: restriction fragment length polymorphisms in the bovine calpastatin gene. Journal of Animal Science 71:2277. https://doi.org/10.2527/ $1993.7182277 x$

Casas, E.; White, S. N.; Riley, D. G.; Smith, T. P. L.; Brenneman, R. A.; Olson, T. A.; Johnson, D. D.; Coleman, S. W.; Bennett, G. L. and Chase Jr., C. C. 2005. Assessment of single nucleotide polymorphisms in genes residing on chromosomes 14 and 29 for association with carcass composition traits in Bos indicus cattle. Journal of Animal Science 83:13-19. https://doi.org/10.2527/2005.83113x

Casas, E.; White, S. N.; Wheeler, T. L.; Shackelford, S. D.; Koohmaraie, M.; Riley, D. G.; Chase Jr., C. C.; Johnson, D. D. and Smith, T. P. L. 2006. Effects of calpastatin and $\mu$-calpain markers in beef cattle on tenderness traits. Journal of Animal Science 84:520-525. https://doi.org/10.2527/2006.843520x

Curi, R. A.; Chardulo, L. A. L.; Silveira, A. C. and Oliveira, H. N. 2008. Alternative genotyping method for the single nucleotide polymorphism A2959G (AF159246) of the bovine CAST gene. Pesquisa Agropecuária Brasileira 43:657-659. https://doi.org/10.1590/S0100-204X2008000500014

Curi, R. A.; Chardulo, L. A. L.; Mason, M. C.; Arrigoni, M. D. B.; Silveira, A. C. and Oliveira, H. N. 2009. Effect of single nucleotide polymorphisms of CAPN1 and CAST genes on meat traits in Nelore beef cattle (Bos indicus) and in their crosses with Bos taurus. Animal Genetics 40:456-462. https://doi.org/10.1111/j.1365-2052.2009.01859.x

Ferguson, D. M.; Jiang, S. T.; Hearnshaw, H.; Rymill, S. R. and Thompson, J. M. 2000. Effect of electrical stimulation on protease activity and tenderness of $M$. longissimus from cattle with different proportions of Bos indicus content. Meat Science 55:265-272. https://doi.org/10.1016/S0309-1740(99)00131-X

Johnson, D. D.; Huffman, R. D.; Williams, S. E. and Hargrove, D. D. 1990. Effects of percentage Brahman and Angus breeding age-season of feeding and slaughter end point on meat palatability and muscle characteristics. Journal of Animal Science 68:1980-1986. https://doi.org/10.2527/1990.6871980x

Koohmaraie, M. 1996. Biochemical factors regulating the toughening and tenderization processes of meat. Meat Science 43(S1):193-201. https://doi.org/10.1016/0309-1740(96)00065-4

Little, J. and Moler, C. 2002. Matlab: the language of technical computing. (Matlab 6.5. Product Family). The MathWorks, Inc. Natick, MA, USA. CD-ROM.

Morris, C. A.; Cullen, N. G.; Hickey, S. M.; Dobbie, P. M.; Veenvliet, B. A.; Manley, T. R.; Pitchford, W. S.; Kruk, Z. A.; Bottema, C. D. K. and Wilson, T. 2006. Genotypic effects of calpain 1 and calpastatin on the tenderness of cooked M. longissimus dorsi steaks from Jersey $\times$ Limousin, Angus and Hereford-cross cattle. Animal Genetics 37:411-414. https://doi.org/10.1111/ j.1365-2052.2006.01483.x

R. Bras. Zootec., 48:e20180218, 2019 
Olerup, O. and Zetterquist, H. 1992. HLA-DR typing by PCR amplification with sequence-specific primers (PCR-SSP) in 2 hours: an alternative to serological DR typing in clinical practice including donor-recipient matching in cadaveric transplantation. Tissue Antigens 39:225-235. https://doi.org/10.1111/j.1399-0039.1992.tb01940.x

Page, B. T.; Casas, E.; Heaton, M. P.; Cullen, N. G.; Hyndman, D. L.; Morris, C. A.; Crawford, A. M.; Wheeler, T. L.; Koohmaraie, M.; Keele, J. W. and Smith, T. P. L. 2002. Evaluation of single-nucleotide polymorphisms in CAPN1 for association with meat tenderness in cattle. Journal of Animal Science 80:3077-3085. https://doi.org/10.2527/2002.80123077x

Page, B. T.; Casas, E.; Quaas, R. L.; Thallman, R. M.; Wheeler, T. L.; Shackelford, S. D.; Koohmaraie, M.; White, S. N.; Bennett, G. L.; Keele, J. W.; Dikeman, M. E. and Smith, T. P. L. 2004. Association of markers in the bovine CAPN1 gene with meat tenderness in large crossbred populations that sample influential industry sires. Journal of Animal Science 82:34743481. https://doi.org/10.2527/2004.82123474x

Regitano, L. C. A. and Coutinho, L. L. 2001. Biologia molecular aplicada à produção animal. Embrapa Informação Tecnológica, Brasília.

Restle, J.; Vaz, F. N. and Pacheco, P. S. 2003. Uso de animais zebuínos em cruzamentos de bovinos de corte no Sul do Brasil. In: Anais do $1^{\circ}$ Simpósio Brasileiro sobre cruzamento de bovinos de corte, Londrina.

Rincón, G. and Medrano, J. F. 2006. Assays for genotyping single nucleotide polymorphism in the bovine CAPN1 gene. Animal Genetics 37:294-295. https://doi.org/10.1111/j.1365-2052.2006.01430.x

Rubensam, J. M.; Felício, P. E. and Termignoni, C. 1998. Influência do genótipo Bos indicus na atividade de calpastatina e na textura da carne de novilhos abatidos no Sul do Brasil. Ciência e Tecnologia de Alimentos 18:405-409. https://doi.org/10.1590/S0101-20611998000400009

Sherbeck, J. A.; Tatum, J. D.; Field, T. G.; Morgan, J. B. and Smith, G. C. 1995. Feedlot performance, carcass traits, and palatability traits of Hereford and Hereford x Brahman steers. Journal of Animal Science 73:3613-3620. https://doi.org/10.2527/1995.73123613x

Smith, T. P. L.; Casas, E.; Rexroad, C. E.; Kappes, S. M. and Keele, J. W. 2000. Bovine CAPN1 maps to a region of BTA29 containing a quantitative trait locus for meat tenderness. Journal of Animal Science 78:2589-2594. https://doi.org/10.2527/2000.78102589x

Soria, L. A.; Corva, P. M.; Huguet, M. J.; Miño, S. and Miquel, M. C. 2010. Bovine $\mu$-calpain (CAPN1) gene polymorphisms in Brangus and Brahman bulls. Journal of Basic and Applied Genetics 21:61-69.

White, S. N.; Casas, E.; Wheeler, T. L.; Shackelford, S. D.; Koohmaraie, M.; Riley, D. G.; Chase Jr., C. C.; Johnson, D. D.; Keele, J. W. and Smith, T. P. L. 2005. A new single nucleotide polymorphism in CAPN1 extends the current tenderness marker test to include cattle of Bos indicus, Bos taurus and crossbred descent. Journal of Animal Science 83:2001-2008. https://doi.org/10.2527/2005.8392001x

Zadworny, D. and Kuhnlein, U. 1990. The identification of the kappa-casein genotype in Holstein dairy cattle using the polymerase chain reaction. Theoretical and Applied Genetics 80:631-634. https://doi.org/10.1007/BF00224222 